\title{
Loan translations versus direct loans: The impact of English on European football lexis
}

\section{Gunnar Bergh \& Sölve Ohlander}

Football language may be regarded as the world's most widespread special language, where English has played a key role. The focus of the present study is the influence of English football vocabulary in the form of loan translations, contrasted with direct loans, as manifested in 16 European languages from different language families (Germanic, Romance, Slavic, etc.). Drawing on a set of 25 English football words (match, corner, dribble, offside, etc.), the investigation shows that there is a great deal of variation between the languages studied. For example, Icelandic shows the largest number of loan translations, while direct loans are most numerous in Norwegian; overall, combining direct loans and loan translations, Finnish displays the lowest number of English loans. The tendencies noted are discussed, offering some tentative explanations of the results, where both linguistic and sociolinguistic factors, such as language similarity and attitudes to borrowing, are considered.

Keywords: direct loans, English football vocabulary, European languages, language policy, loan translations

Gunnar Bergh, University of Gothenburg, Department of Languages and Literatures, P.O. Box 200, S-40530 Gothenburg, Sweden. gunnar.bergh@sprak.gu.se

Sölve Ohlander, University of Gothenburg, Department of Languages and Literatures \& Department of Education and Special Education, P.O. Box 200, S-405 30 Gothenburg, Sweden.

solve.ohlander@ped.gu.se

\section{INTRODUCTION}

Today's interest in football - i.e. soccer or association football - is an astonishing feature of everyday life around the globe, whether regarded as a mere sport or as a pop or mass cultural phenomenon. Giulianotti (1999:23) considers football 'one of the great cultural institutions'; Goldblatt (2007:x) asks the following, largely rhetorical question: 'Is there any cultural practice more global than football?'. This means, among other things, that vast numbers of people throughout the world communicate about football on a more or less daily basis. It also implies that the language used in communication about football in a variety of contexts (on and off the pitch, in speech and writing, by players and officials, fans and commentators) should not only be seen as a 'special language' - an LSP, a language for special purposes - in the sense of Sager, Dungworth \& McDonald (1980:68), although arguably the world's 
biggest. Football language can also, in view of the game's massive appeal and media coverage, be seen as a kind of 'public' language, in ways not shared by other special languages, e.g. those of medicine, law or linguistics (Bergh \& Ohlander 2012a:14). ${ }^{1}$ It is symptomatic that a large amount of technical football vocabulary has made its way into general language, and is included as a matter of course in general-purpose desk dictionaries, e.g. forward, free kick, kick-off and offside. ${ }^{2}$ A further indication is that football expressions such as scoring an own goal and moving the goalposts have been adopted as metaphorical usage in general language, not only in English (see e.g. $O D E$ ).

The dual nature of football language - a special as well as a public language - is not altogether a recent phenomenon, although clearly enhanced since the late 20th century. It dates back more than a hundred years, when British football was conquering the world (see e.g. Goldblatt 2007:112ff.), also spreading the language of the game, not least the technical terms associated with it.

Thus, due to its roots in 19th-century Britain, coinciding with the expansion of the British Empire and the role of English as an increasingly global language throughout the 20th century, there is still what may be called an 'English bias' (Bergh \& Ohlander 2012a:13) in today's international football language. It is most easily noticed in the field of vocabulary and phraseology, the linguistic component that most readily signals the identity of any special language (see Sager et al. 1980:230) - albeit not exclusively so. ${ }^{3}$ For example, a term like offside turns up as a direct loan in many languages, e.g. Swedish; in other languages, it is (nowadays) rendered as a loan translation, such as German abseits. Similarly, the word football itself - 'the world's best-known word', according to Seddon (2004:89) - may be recognized as a direct loan in Japanese, in the phonologically modified form fotuboru, but as a loan translation in e.g. Swedish fotboll.

As the above examples will have hinted, two main strategies are in evidence when it comes to borrowing English football vocabulary: direct loans and loan translations (or calques). ${ }^{4}$ Both of them are, of course, well known from other fields of lexical borrowing (see Haugen 1950). Different languages may, at different times, lean more or less heavily towards one of them. From another perspective, different lexical items may, for various reasons, be more or less prone to one or the other type of borrowing. In the process, some of them may even give rise to the emergence of so-called false friends in certain languages (for Swedish, see Bergh \& Ohlander 2014).

Regardless of perspective, the cross-linguistic impact of English on international football vocabulary is obvious, particularly with regard to European languages. It should therefore be of interest to study, in some more detail, how English football vocabulary has fared when exported to other European countries and languages, especially concerning the two main strategies for borrowing just mentioned. Our overall purpose in this study is to investigate what happened to a number of central English football-related expressions when imported by various European languages, 
with different degrees of historical and/or typological closeness to English. Our main focus here will be on loan translations. To get a proper view and a fuller perspective of this type of loan in the languages investigated, it will also be necessary to include direct loans in the discussion. In other words, loan translations will be studied in relation to direct loans in a specifically European language and footballing context.

\section{AIMS AND DESIGN}

The present investigation is a follow-up study of Bergh \& Ohlander (2012b), which focused on 25 English football terms adopted, to varying degrees, as direct loans -i.e. 'recognizably English in form' (Görlach 2001:xviii) - in the football vocabularies of 16 European languages (see Section 3 below). It involves the same 25 words and the same languages as in the previous investigation and should be seen as a comparative study of the extent to which loan translations of English football terminology turn up in the languages under scrutiny. It should be emphasized that the main focus is qualitative rather than strictly quantitative, even though some quantitative measures are needed as a starting point. The specific aims and methodology of the present investigation, where direct loans will often serve as backdrop, closely parallel those of the previous study, the only difference being that our present focus is on loan translations rather than direct loans.

With regard to the vocabulary items investigated and the various European languages involved, our aims in this study reflect two distinct, complementary perspectives, or questions:

(1) Which of the English football terms studied have been most, or least, apt to be converted into loan translations rather than direct loans? Possible reasons?

(2) Which of the languages studied have been most, or least, inclined to convert English football terms into loan translations rather than direct loans? Possible reasons?

The quantitative outcome of the research questions just specified, leading on to qualitative discussions concerning factors and circumstances of relevance for the data obtained, will be basically accounted for in the form of frequency tables involving the football terms and languages investigated. Thus, the quantitative results are intended to pave the way for considerations bearing on, in particular, why some English football terms lend themselves more readily to loan translation than others; or why some languages are apparently more - or less - inclined to convert English football terms into loan translations than others, which instead seem to favour direct loans.

The overall design - material and method - of the present study is the same as in our previous study of direct loans. The material, in the form of 25 footballrelated terms borrowed in 16 European languages, was taken from Manfred Görlach's 
A Dictionary of European Anglicisms (Görlach 2001; henceforth DEA), which is a convenient - or rather, indispensable - source of information for the kind of cross-linguistic study undertaken here. Based on 'the lexical input of English into European languages up to the early 1990s' (Görlach 2001:xvi), DEA gives detailed information, both formal and functional/semantic as well as historical, on Anglicisms in 16 European languages, collected by a group of some 20 specialists in the languages concerned (see also Görlach 2002). Among the Anglicisms included are a fair number of football-related and other sports terms. Of special relevance for our purposes is the information supplied in the volume as to whether a certain word should be classified as a direct loan, loan translation or some other 'indigenous creation'. However, the term 'loan translation' in itself, as applied in DEA, is not unproblematic (see Section 4.1). Further, it should be noted that only such English words as appear as direct loans in at least one of the 16 languages are included in the dictionary (Görlach 2001:xxvi); consequently, English words or expressions that have been rendered only as loan translations in all of the 16 languages are not accounted for e.g. common football terms like crossbar, defence, free kick, pitch and set piece. This feature of DEAwell justified in its own right but a potential complication in the present context should be kept in mind and will merit some further discussion in due course.

Obviously, relying on $D E A$ means that the material of our two studies cannot be characterized as fully up-to-date. However, the chief aim of these studies is not to chart the present-day situation in any detail, but rather to raise and discuss some general questions in connection with the borrowing of football terminology in a European context. A more detailed account of today's situation with regard to such borrowing would have prompted another, more multi-faceted methodological approach, with other sets of data, along the lines of the large-scale Nordic-language project Moderne importord i språka i Norden (the MIN project) outlined in e.g. Kristiansen \& Vikør (2006) and Kvaran (2007a); see also Kristiansen \& Sandøy (2010)..$^{5}$ This, however, would have implied a much larger undertaking, an altogether different study. For our more restricted comparative purposes, DEA appears to us - despite certain problematic aspects - to serve reasonably well as a starting point for a more general account of certain tendencies and issues in the field of European football vocabulary, involving processes that may also be assumed relevant in a more recent context of direct loans versus loan translations.

The selection of languages in $D E A$ has provided the framework for the present as well as our previous study of English loans in European football lexis, i.e. '16 European languages, from different language families, but excluding those in close contact with English (e.g. Irish, Welsh, and Maltese)' (Görlach 2001:xv). Besides different language families, there is a fair range of typological variation concerning, for example, phonological and morphological structure, as well as type of alphabet used.

Table 1 shows the 16 languages grouped into four language-family categories, with four languages in each group, the fourth ('other') being a miscellaneous 
one, where Finnish and Hungarian stand out as the only two non-Indo-European languages.

\begin{tabular}{llll}
\hline Germanic & Romance & Slavic & Other \\
\hline Dutch & French & Bulgarian & Albanian \\
German & Italian & Croatian & Finnish \\
Icelandic & Romanian & Polish & Greek \\
Norwegian & Spanish & Russian & Hungarian \\
\hline
\end{tabular}

Table 1. The 16 European languages included in DEA.

If the choice of languages to be included in our joint investigation was unproblematic, being simply taken over from $D E A$, selecting the English words proved somewhat more complicated. Altogether, the dictionary accounts for approximately 90 lexical items marked as being part of the football or sports domain (e.g. goal and score). Out of these, 25 words were chosen, providing clear examples of football-related language, as shown in Table 2.

\begin{tabular}{lllll}
\hline back & draw & hands & kick-off & shoot \\
coach & dribble & hat-trick & match & supporter \\
corner & football & head & offside & sweeper \\
cross & forward & hooligan & penalty & tackle \\
derby & goal & keeper & score & team \\
\hline
\end{tabular}

Table 2. The 25 football words investigated.

As can be seen in Table 2, nouns predominate in the group of words selected for the investigation: no fewer than 20 of them are nouns (or noun-like items). Five of them are verbs (dribble, head, score, shoot, tackle), as classified by DEA. Thus, it is their use as verbs that justifies their inclusion as football words in $D E A$, and in our material, despite the fact that they may all, as English words, also occur as nouns. ${ }^{6}$ This somewhat lopsided word-class distribution reflects the fact that, generally speaking, nouns are much more common than verbs, football being no exception. ${ }^{7}$ It may be added that the words chosen belong to different layers, or dimensions, of the football-related domain. The majority of them are part of the very core of the game (e.g. dribble, kick-off), while others may be seen as somewhat more peripheral (e.g. coach, hooligan); see Bergh \& Ohlander (2012a:18f.). This is mainly due to the fact that some of the words are more general than others, tending to show up in several other sports, as well as in more general-language contexts (e.g. goal, penalty and team). In any event, the words selected can be said to represent football language in a wide sense, being made up of lexical items commonly used with football-related reference - albeit not always exclusively so. ${ }^{8}$ 
Morphologically, the majority of the words are simple, monomorphemic ones, such as back, cross, dribble and tackle. Three of them are agentive nouns derived from verbs: keeper, supporter and sweeper. The verb particle off turns up as a prefix in offside, as a suffix in kick-off. By contrast, football and hat-trick are fullblown compounds - of some relevance to the notion of 'loan translation' (see Section 4.1).

\section{DIRECT FOOTBALL LOANS: SUMMARY OF MAIN FINDINGS IN PREVIOUS STUDY}

As a necessary backdrop to the present study, where the focus is on loan translation in relation to the 25 football words and the 16 languages investigated, this section provides a summary of the main results and issues discussed in the previous study, intended to prepare the ground for a comparison of how the English loans investigated have been received in the languages under discussion. For details concerning individual words and languages, as well as more in-depth discussion of the results briefly accounted for here, the reader is referred to the original study (Bergh \& Ohlander 2012b). ${ }^{9}$

Like the present study, the previous one was two-pronged, involving a combination of 25 football words and 16 languages. This dual perspective is reflected in the following subsections.

\subsection{Distribution of direct football loans across languages}

Starting from the 25 words, it was shown that there are substantial differences in their frequency of occurrence as direct loans among the 16 languages. This can be seen in Table 3 below, a ranking list demonstrating the direct-loan frequency of each of the English football terms studied. This table, then, can be said to display the relative direct-loan 'popularity' of the individual words across the languages studied, as expressed by the number of languages where, according to $D E A$, they have been adopted as direct loans. As is clear from Table 3, the English football words differ in attractiveness as direct loans. In the topmost position we find team, occurring as a direct loan in all of the languages. At the bottom, the verb head occurs only in one of them - Norwegian (see Section 3.2) - while the verb shoot, for example, is to be found as a direct loan in nine languages.

In terms of frequency, three groups may be broadly distinguished although, admittedly, the borderline between, especially, groups (ii) and (iii) is not clear-cut:

(i) a top group of 13 words (team to penalty), appearing as direct loans in at least 75 per cent of the 16 languages (range: 12-16 languages)

(ii) an intermediate group of five words (forward to keeper), found as direct loans in about half of the 16 languages (range: 5-9 languages) 
(iii) a bottom group of seven words (cross to head), to be recognized as direct loans in only 25 per cent, or less, of the 16 languages (range: 1-4 languages)

\begin{tabular}{llll}
\hline Direct loans & $\begin{array}{l}\text { Number of } \\
\text { languages }\end{array}$ & Direct loans & $\begin{array}{l}\text { Number of } \\
\text { languages }\end{array}$ \\
\hline team & 16 & forward & 9 \\
hooligan & 15 & shoot & 9 \\
offside & 15 & hands & 7 \\
corner & 14 & kick-off & 6 \\
derby & 14 & keeper & 5 \\
dribble & 14 & cross & 4 \\
goal & 14 & supporter & 4 \\
hat-trick & 14 & tackle & 4 \\
match & 14 & score & 3 \\
back & 12 & draw & 2 \\
coach & 12 & sweeper & 2 \\
football & 12 & head & 1 \\
penalty & 12 & & \\
\hline
\end{tabular}

Table 3. Direct English football loans adopted by the 16 languages.

A closer look at these three groups will reveal, among other things, that a clear majority of the words in the top group express basic football concepts relating to the structural or functional core of the game (e.g. team, corner, goal, back, penalty). It may also be noted that dribble is the only verb to make it into the top group, whereas the remaining four verbs (shoot, tackle, score, head) are considerably less common as direct loans.

As regards possible reasons why some English words lend themselves to direct borrowing more readily than others - a subject highly relevant to loan translation (see Section 4) - notions like semantic specificity and complexity, closely related to translatability in a wide sense (see Baker 1998:273ff.), may play a significant role. For example, the verb dribble is clearly more complex, and specific, in its semantic makeup than more straightforward football verbs like shoot and score, which are also much more common outside the football domain. This may be at least part of the reason why so many languages (14 out of 16) have adopted it as a direct loan; finding a proper native equivalent to dribble is not all that easy. Another example is offside. It is probably no coincidence that both these 'football-specific' words require lengthy and rather involved definitions in order for their respective meanings to be (at least approximately) conveyed. ${ }^{10}$

It appears, however, that it is not generally possible to explain why a specific football word was adopted as a direct loan in a certain language, while another was not. For example, why were penalty and corner adopted as direct loans in so many 
languages, while defence or free kick (not included in $D E A$ ) was not? Why did the verb score turn up as a direct loan in Dutch but not in German? Similar questions are relevant to borrowing in general, not only to football vocabulary. In this connection, some additional factors, having to do with borrowing in relation to language planning and maintenance, have to be taken into consideration, involving attitudinal differences among individual languages concerning their readiness - which may vary between different periods - to adopt direct loans. Such aspects will be briefly touched on in the following subsection.

\subsection{Propensity of individual languages to adopt direct football loans}

Changing the focus from the 25 words to the 16 languages investigated, the basic questions are to what extent the languages investigated differ as to their willingness to accept direct football loans from English, and how - if at all - such differences can be explained. The latter question, however, cannot be fully treated within the confines of this summary; for some more in-depth discussion, see Bergh \& Ohlander (2012b:295ff.; see also Section 6 below).

The variation among the languages investigated as regards their tendency to adopt direct English football loans is illustrated in Table 4 below, sorted (in order of decreasing frequency) according to the number of direct loans (out of the 25 English words) each language has adopted.

As is readily seen, there are striking differences between languages as regards their propensity to accept English direct loans within the football domain. However, a caveat is in order. As will be argued later on, the time factor is highly relevant for attitudes to borrowing in different languages; such attitudes may change over time. Table 4 provides what may be described as a cumulative, historical picture of the overall situation in the 16 languages during a time span of a hundred years or so, according to the data collected from $D E A$. Thus, it should not, generally speaking, be taken to reflect the present-day propensity of the various languages to pick up English direct football loans; nor does it necessarily mirror the current situation concerning direct loans in each language. Even for the same language, the historical situation may not be identical in different countries. ${ }^{11}$

At the very top of Table 4, we find Norwegian, in splendid isolation, with no fewer than 23 direct loans out of the 25 English football words. ${ }^{12}$ Dutch, another Germanic language comes in second (20 direct loans), while German occupies a shared third place (together with Croatian and Romanian). This might give an impression that relatedness, or perhaps similarity, to the loan-giving language is key to explaining the propensity - or lack thereof - of individual languages to pick up direct loans from a specific language. However, consideration of the low position of Icelandic (closely related to Norwegian) in Table 4, with a meagre ten direct loans, only Finnish - a 


\begin{tabular}{llll}
\hline Languages & $\begin{array}{l}\text { Number of } \\
\text { direct loans }\end{array}$ & Languages & $\begin{array}{l}\text { Number of } \\
\text { direct loans }\end{array}$ \\
\hline Norwegian & 23 & French & 14 \\
Dutch & 20 & Polish & 14 \\
Greek & 17 & Russian & 14 \\
Croatian & 16 & Bulgarian & 13 \\
German & 16 & Italian & 13 \\
Romanian & 16 & Albanian & 12 \\
Hungarian & 15 & Icelandic & 10 \\
Spanish & 15 & Finnish & 6 \\
\hline
\end{tabular}

Table 4. Propensity of the 16 languages to adopt direct English football loans.

Finno-Ugric language - being less prone to adopt direct English football loans, may serve as an antidote to such a simplistic idea. Obviously, as also indicated by the relative positions of other languages, the situation is far more complex; readiness to import direct loans does not appear to depend solely, or even primarily, on either genetic relatedness or typological similarity between languages.

It thus appears that purely linguistic factors cannot alone explain the variation in direct-loan propensity across different languages as displayed in Table 4; this applies, of course, not only to football-related loanwords. Other relevant factors, it may be assumed, include international contacts over time - e.g. migration, business relations and cultural exchange - which may promote language contact and exposure to foreign languages. Geographical distance - or geopolitical position - may also be relevant, facilitating international exchange (see Battarbee 2002:263), in turn affecting linguistic attitudes and, often, paving the way for lexical borrowing, especially from high-prestige global languages, such as English from the late 19th century onwards (Crystal 2003:59ff.). However, there are many other relevant variables involved: historical, sociocultural and educational, among others. All of these may, each in their own way, contribute to specific views on language and languages in different countries, at different times, occasionally resulting in an officially codified policy as the ultimate political expression of national attitudes in language matters. ${ }^{13}$

In other words, the propensity of a certain language to adopt direct English football loans is most likely the result of a complex interplay of linguistic and other factors. In this connection, Icelandic, mentioned earlier as an exception to the Germanic-language tendency to pick up direct football-related loans from English, is of particular interest. Iceland, being a small nation in the middle of the North Atlantic, has had a largely successful tradition of restricting the import of foreign words by creating Icelandic alternatives, often in the form of loan translations (see Kvaran \& Svavarsdóttir 2002:84ff., 99; Kvaran 2007b; Óladóttir 
2009; Jansson 2013, 2015). This means that Icelandic can be cited as evidence that fairly close linguistic relatedness (cf. the other three Germanic languages in Table 4) can be counterbalanced by a deliberate policy of opposition to foreign loanwords. A purist attitude may also be the main reason for the bottom position of Finnish, possibly helped by its genetic and typological distance from English (see Battarbee 2002:262ff.; Hiidenmaa \& Nuolijärvi 2004:271f.). By contrast, purist agendas concerning Norwegian and Dutch (top of Table 4) have apparently not met with the same success as in Icelandic and Finnish (see Berteloot \& van der Sijs 2002:40; Graedler 2002:60f.). Again, the main point is that linguistic relatedness or similarity does not in itself present a necessary and sufficient condition for large-scale import of direct loans. Rather, national attitudes to foreign languages and borrowing seem to play a key role in shaping approaches to language planning and maintenance, affecting the influx of foreign loans (see Kvaran 2007b:16f.). Consideration of other languages than those just mentioned - e.g. French, Spanish, Greek, Croatian and Hungarian - points in the same direction (Bergh \& Ohlander 2012b:297ff.)

Summing up, neither linguistic similarity nor geographical distance appear, on their own, to carry much weight in accounting for the propensity of a language to adopt direct football loans from English. What seems to be at work, rather, is a combination of more contingent factors, related to 'softer' variables like language attitudes as well as a plethora of historical and sociocultural circumstances. In particular, the combined effect of language attitudes at the time football was introduced into a language community, the social characteristics of those who embraced the new game, its national development and popularity, etc., will most likely have mattered more than purely linguistic factors (see Haugen 1950:224f.).

\section{LOAN TRANSLATIONS}

Bearing in mind the patterning of direct football loans, we now proceed to our main concern in the present paper: the distribution of the same 25 words considered from the perspective of loan translation in the 16 languages investigated. More specifically, the following questions will be addressed, repeated here (from Section 2) for convenience: (1) Which of the English football terms studied have been most, or least, apt to be converted into loan translations rather than direct loans? Possible reasons? (2) Which of the languages studied have been most, or least, inclined to convert English football terms into loan translations rather than direct loans? Possible reasons? Obviously, these two questions involve a comparative perspective - loan translations versus direct loans as accounted for in the previous section.

As hinted earlier, loan translation is in many ways less easy to handle than direct loans, a point deserving some special attention. Further, to get a more complete picture of the interplay between direct borrowing and loan translation in the material 
studied, their relationship is also discussed in Section 5, from a combined perspective of direct loans and loan translations.

\subsection{Distribution of loan translations across languages}

The basic question in this section concerns which of the 25 football words are most, or least, inclined to be loan-translated in the 16 languages studied. In our discussion, some possibly relevant matters will be briefly touched on in relation to the results, purely linguistic ones as well as others of a more sociolinguistic nature (see also Sections 5 and 6). First, however, certain complicating factors of a methodological nature need to be looked into. In particular, the term 'loan translation' as used in DEA demands some critical attention, alongside of some other issues in connection with the words studied, having a clear bearing on our results. In addition, we shall have occasion, further on in this section, to return to the criteria for inclusion of words in $D E A$.

The interplay between direct loans and loan translations in a comparative language perspective is implicit in any discussion of direct loans within a specific semantic domain, such as football vocabulary. On the whole, some kind of trading relation between direct loans and loan translations might be expected, in that a large number of direct loans would likely imply a proportionately lower number of loan translations. While there is certainly some truth to this, the overall picture is rather more complicated.

For one thing, a direct loan and a loan translation may co-exist for a lengthy period of time as alternative expressions in a language, although they may be used in different contexts, e.g. corner versus hjørnespark in Norwegian (Graedler \& Johansson 1997: corner; Kvaran 2007c:172; see also below). Further, as argued earlier, the time dimension is in itself important, since attitudes to direct loans may change in the course of a century or so, affecting the introduction and use of loan translations in the process; compare e.g. offside in English and abseits in German, mentioned earlier. In this study, as already pointed out, the time dimension is largely disregarded: if a direct loan or loan translation is recorded in $D E A$ for a certain language, it is counted as such in our results, regardless of whether it is still in use. In other words, there is no simple either-or relation between direct loans and loan translations in our material, a state of affairs that is certainly recognizable in other domains than football vocabulary.

A more serious complication is the fact that the notion of 'loan translation' (often also referred to as 'calque') is hardly clear-cut. It is typically exemplified by compounds, involving morpheme-by-morpheme translation (see e.g. Ljung 1988:72ff.; Edlund \& Hene 1992:34; Kvaran 2007c:185; Stålhammar 2010:34), such as the rendition of football and free kick as, respectively, fotboll and frispark in Swedish. However, the exact scope of the term remains unclear. Different scholars 
tend to use it differently, especially in relation to so-called semantic loans, such as the footballing sense of the verb shoot, grafted onto the corresponding verb in many other languages, as in Swedish skjuta and Dutch schieten. Now, should such cases be seen as a type of loan translation or as a separate category, and, if so, on what grounds? This, it seems to us, is a matter of partly arbitrary classification rather than a question of right or wrong. That semantic loans and loan translations are closely related seems beyond doubt, as is clear from the stated views of a number of scholars, among them some Scandinavian ones. Haugen (1950:214f.) regards semantic loans as 'closely related' to loan translations; both of them are subsumed under the superordinate category of 'loanshifts'; see also Schütte (1996:35). In a similar vein, Ljung (1988:60, 72) sees semantic loans as a special type of loan translation, while Graedler \& Johansson (1997:10) classify loan translations and semantic loans as different types of 'indirect loans', a view resembling that of Edlund \& Hene (1992:34f.). Stålhammar (2010:25) avoids the issue, stressing the problematic nature of semantic loans from the point of view of categorization. Görlach (2001:xxvi), in turn, appears to use (but not consistently so; see page xxv) the term 'calque' as a superordinate category (similar to 'indirect loans') in relation to loan translations and semantic loans; usually, however, it is regarded as a synonym of loan translation (see e.g. Haugen 1950:214; Busse \& Görlach 2002:26; Crystal 2010:340).

Another issue concerns the degree of latitude allowed for an indigenous expression to be termed a loan translation. For example, it is not self-evident that Italian calcio d'inizio for kick-off should be considered a loan translation; in $D E A$, however, it seems to be, at least if the notational conventions in the dictionary are to be taken at face value. There is, in fact, often a difference between theory and practice in $D E A$ as regards categorization. In his introduction, Görlach (2001:xxv) states that if the word is clearly calqued on the English lemma it is preceded by one of the following labels: trans (translation), rend, (rendition) or creat (creation)'; however, no criteria are offered. Italian calcio d'inizio, surely a paraphrase - or 'creation' in the sense of Haugen (1950:220), i.e. not strictly a loan at all - rather than a (clear) calque, is actually labelled 'rend' in $D E A$, thus classified as a type of calque (as opposed to e.g. French coup d'envoi for kickoff). Further, with regard to semantic loans: 'if only the meaning is borrowed (and added to a pre-existing word), the word is preceded by "mean" (borrowed meaning)' (Görlach 2001:xxv).

In actual practice, $D E A$ suffers from a certain (and possibly inevitable) lack of consistency in applying its classification. Another example involves Dutch schieten 'shoot' (cf. above), which would usually be regarded as a semantic loan but is not marked 'mean' in DEA, whereas Norwegian skyte and Icelandic skjóta, equally clear semantic loans, are both marked 'trsl', i.e. as loan translations. Apparently, Görlach is well aware of the difficulty, in practice, of using the proposed distinctions and notations rigorously and consistently throughout the DEA material: 'Needless to say, 
all these categories provide many doubtful cases, and in consequence, subjective decisions - a problem magnified by the large number of collaborators' (Görlach 2001:xxvi).

The questions brought up in the preceding paragraphs are important ones, relevant to the results of this study, especially when it comes to the category of loan translation. In view of the relative vagueness of the category as implemented in $D E A$, and with the wisdom of hindsight, it might have been better to opt for a simpler dichotomy, involving direct loans versus indigenous expressions of whatever kind, regardless of type. On the other hand, it is undoubtedly the case that loan translations and semantic loans share the specific element of direct translation, whether of compound words like football or morphologically simple words like shoot or corner. From this point of view, it would, for our purposes, have been justified to collapse loan translations and semantic loans into a superordinate category of, say, 'indirect loans', as proposed by e.g. Graedler \& Johansson (1997:10).

Nonetheless, despite the problems involved, we decided to follow $D E A$ 's classification of our material. This means, in practice, that $D E A$ 's use of the term 'loan translation' covers many cases - especially simple words like corner and shoot - that other scholars regard as prime examples of semantic borrowing. Thus, the notion of loan translation is here used in a wide sense. Indeed, the basic dichotomy in the $D E A$ material investigated here could be construed as one of direct borrowing versus direct translation. By and large, we do not believe that the overall pattern has been substantially affected by a few cases of possibly dubious categorization concerning loan translations and semantic loans.

Summing up the above discussion, our main concern is the contrast between direct loans and loan translations in a wide sense, following $D E A$ 's classification in individual cases. The main thing, in our view, is the basic difference between borrowing where formal/phonological features from the original language are taken over by the borrowing language with varying degrees of adaptation (direct loans) and borrowing where a more or less direct translation of the foreign word is the key element (loan translations in a wide sense). Apart from completely indigenous creations (paraphrases, etc.), these are the two main strategies as far as borrowing is concerned, where differences with regard to individual words in different languages studied are to be expected.

Table 5 accounts for the tendency of each of the 25 English football terms to be converted into corresponding loan translations in the 16 languages. First of all, it should be noted that Table 5 is not a mere reversal of Table 3 (Section 3.1), accounting for direct loans in relation to the number of languages that have adopted them. A case in point is the word offside, with loan translations in three languages versus direct loans in 15, adding up to 18 cases of borrowing in the 16 languages investigated. An even more striking example is corner at the top of Table 5: a loan translation in eleven languages versus a direct loan in 14, adding up to 25 cases of 


\begin{tabular}{llll}
\hline $\begin{array}{l}\text { Loan } \\
\text { translations }\end{array}$ & $\begin{array}{l}\text { Number of } \\
\text { languages }\end{array}$ & $\begin{array}{l}\text { Loan } \\
\text { translations }\end{array}$ & $\begin{array}{l}\text { Number of } \\
\text { languages }\end{array}$ \\
\hline $\begin{array}{l}\text { corner } \\
\text { football }\end{array}$ & 11 & dribble & 1 \\
penalty & 9 & goal & 1 \\
back & 6 & head & 1 \\
hands & 5 & hooligan & 1 \\
forward & 5 & team & 1 \\
offside & 3 & coach & 0 \\
hat-trick & 3 & derby & 0 \\
keeper & 2 & draw & 0 \\
kick-off & 2 & match & 0 \\
shoot & 2 & score & 0 \\
sweeper & 2 & supporter & 0 \\
cross & 2 & tackle & 0 \\
\hline
\end{tabular}

Table 5. Loan translations of 25 English football words in the 16 languages.

borrowing in the 16 languages studied. The reason for this seemingly paradoxical state of affairs has already been mentioned: there is no mutually exclusive either-or relation between direct loans and loan translations (or other indigenous equivalents) in the various languages. It is by no means rare for a direct loan and a loan translation to be used, temporarily or for a longer period of time, as alternative expressions, often in somewhat different contexts. This is jointly reflected in Tables 3 and 5; a combined perspective of direct loans and loan translations will be provided in Section 5. Further, loan translation represents just one way of converting foreign words into indigenous ones.

More importantly, even a superficial glance at Tables 3 and 5 will reveal that the 25 English football terms investigated have been clearly more prone to be adopted as direct loans than being converted to loan translations. Indeed, it is a striking feature of Table 5 that the total number of loan translations across the 16 languages is much lower than the corresponding number of direct loans in Table 3: 58 versus 234 . This means that loan translations make up a mere 25 per cent of the corresponding number for direct loans, or, expressed differently, 20 per cent of the total number of borrowings (292). Further, as a closer inspection of Tables 3 and 5 will demonstrate, this overall difference is also reflected in the individual numbers for each of the football words investigated.

Generally speaking, the proportion between loan translations and direct loans in the material studied may be characterized as far from self-evident, a circumstance that should be further looked into. The basic question is whether the difference observed in the material may be seen as broadly representative with regard to borrowed football vocabulary in general, or whether it should be seen as a kind of (partial) artefact due to the nature of the material itself. 
For some elucidation of the underlying issue, let us take a closer look at Table 5. At the top of the table, we find the words corner and football, whose propensity for being calqued is considerably greater than that of the other words. At the same time, they clearly lag behind the direct-loan popularity of the top words in Table 3. At the bottom, there is a group of seven words not showing any instances, in any language, of loan translation, preceded by a group of six words with only one occurrence each among the languages investigated. Accordingly, more than half (13) of the 25 English football terms turn up as loan translations in less than two out of the 16 languages accounted for in DEA. Again, the difference in relation to direct loans (Table 3) seems to speak for itself. Or does it?

The clue to what appears to be a surprising and counterintuitive outcome of our investigation lies in the material itself. It should be borne in mind that the selection of words for this study was made on the specific grounds that they represent what appear to be typical football Anglicisms, i.e. direct loans, in a number of European languages (see Section 2). In other words, the selection of football terms was not neutral between direct loans and other types of borrowing; on the contrary, it was heavily biased in favour of direct loans, a side effect of using DEA as our source of material. As mentioned earlier, a frequent football term like free kick, usually rendered as a loan translation in other languages, in contrast to offside and dribble, was never a proper candidate for inclusion in our selection. This is due to the fact that it is not included in $D E A$, since it does not meet the requirement of appearing as a direct loan in at least one of its 16 languages. Naturally, a random selection drawn from the totality of English football vocabulary, where words like offside and free kick would have had an equal chance of inclusion, would have yielded a different result as to the balance between direct loans and loan translations.

Consequently, it would be unwarranted to conclude, on the basis of the present investigation, that football vocabulary in general is more prone to borrowing in the form of direct loans than in the form of loan translations. Such a conclusion is valid only for the 25 words selected for investigation in the present study and cannot be extrapolated beyond it. In other words, the specific proportion between direct loans and translation loans emerging from the present study can indeed be seen as a partial artefact of $D E A$ 's principles for inclusion - which, of course, does not necessarily mean that it can be dismissed as irrelevant. Further, more importantly, $D E A$ offers definite advantages with regard to the wealth of information provided on individual loans in all the 16 European languages covered, enabling the comparative, crosslinguistic approach employed here.

Even though detailed comments on each word in Table 5 cannot be made, a few observations of general interest may be offered. At the very top of the table we find corner, with loan translations in eleven languages. As a football term, it can be described as an ordinary, everyday word to which a special meaning - as defined by football's rule system - has been added. According to DEA (corner), the English 
word was an early adoption, i.e. 'around 1900'; 'the term was frequently replaced by obvious native equivalents, but remained available locally (e.g. for German in Austria) or as a fashionable alternative'. Arguably, the ordinariness of the word's basic locative meaning, expressed by corresponding everyday words in other languages, may have facilitated its frequent conversion into loan translations, e.g. Icelandic horn(spyrna). At the same time, corner as a direct loan is documented in no fewer than 14 languages (see Table 3). Thus, as noted in DEA, it has been borrowed, in many languages, as both a direct loan and a loan translation; compare Norwegian corner and hjørne(spark). ${ }^{14}$

The second most frequent loan translation is the word football itself, occurring as a loan translation in nine languages. According to DEA (football), '[t]his word for soccer was almost universally adopted into Continental languages from the late nineteenth century onwards, but was later replaced by calques in some'. This tendency is reflected in Table 3 (football as a direct loan in twelve languages) versus Table 5 (football as a loan translation in nine languages). It is of some interest to note that in Italian the English direct loan was more or less supplanted by calcio, whereas the Spanish native equivalent balompié was less successful in ousting fútbol. In a way, this situation may be seen as contrary to expectation, in view of the difference in attitude to direct loans between these two languages, Italian being regarded as having been, generally speaking, more open, or 'liberal', than Spanish (see González 2002:132; Pulcini 2002:153). The case of football thus demonstrates, again, the idiosyncratic, unpredictable nature of borrowing as far as individual expressions are concerned.

The two 'football-specific' terms offside and dribble have already been briefly mentioned (Section 3.1) in connection with semantic specificity and complexity, as well as relative translatability. It is interesting to note, therefore, that these words display a very small number of loan translations, offside in three languages and dribble in only one (Icelandic, not unexpectedly). In comparison with their occurrences as direct loans (15 and 14, respectively; see Table 3), the difference is striking. Apparently, these football terms do not lend themselves easily to translation of the transparent, direct kind typical of loan translation proper. ${ }^{15}$ Consequently, they have more often than not remained as direct loans with well-defined technical meanings. In a few cases, however, the direct loans have been replaced by other - semantically more distinctive - native alternatives than loan translations, such as Spanish fuera de juego for offside.

Finally, something should be said about the seven words making up the bottom group in Table 5, i.e. the words (coach to tackle) not showing any loan translation equivalent in any of the 16 languages. Of these words, derby, match and coach turn up frequently as direct loans, in 12-14 languages (see Table 3). This may be partly due to their semantic makeup, not easily captured in loan translations. Further, in many languages, they appear to lack obvious 'non-football' equivalents to which a new footballing sense could easily be added. This, it would appear, makes conditions for 
loan translation far from optimal, even though other types of native expressions have occasionally tended to replace the direct loans, as in the case of Spanish encuentro for match.

By contrast, the remaining words in the bottom group - supporter, tackle, score and draw - are much less frequent as direct loans (2-4 languages; see Table 3). However, like the three words discussed in the preceding paragraph, they seem to invite independent, semantically more transparent equivalents or paraphrases rather than mere loan translations. The verbs tackle and score, with their football-specific meanings, can be seen as prime examples.

\subsection{Propensity of individual languages to use loan translations}

Let us now, as in our previous study (Section 3), shift the perspective, using the 16 European languages as our starting point with regard to loan translation. Table 6 gives the primary data, organized as a list of top languages according to the number of loan translations recorded for each of them.

\begin{tabular}{llll}
\hline Languages & $\begin{array}{l}\text { Loan } \\
\text { translations }\end{array}$ & Languages & $\begin{array}{l}\text { Loan } \\
\text { translations }\end{array}$ \\
\hline Icelandic & 15 & Russian & 3 \\
German & 6 & Finnish & 2 \\
Norwegian & 6 & Romanian & 2 \\
Bulgarian & 5 & Spanish & 2 \\
Italian & 5 & Croatian & 1 \\
Dutch & 3 & Greek & 1 \\
French & 3 & Polish & 1 \\
Hungarian & 3 & Albanian & 0 \\
\hline
\end{tabular}

Table 6. Propensity of the $\mathbf{1 6}$ languages to use loan translations.

Our discussion of the findings accounted for in Table 6, displaying great crosslinguistic variation, will be fairly brief. First of all, it should be remembered that $D E A$ 's categorization of loan translations versus other types of equivalent expressions, especially semantic loans, is not unproblematic, which may have affected the number of loan translations specified in Table 6. Likewise, the bias towards direct loans in the $D E A$ material, also discussed in the previous section, should be kept in mind with regard to the relative scarcity of loan translations in the languages studied. The results accounted for in Table 6 nonetheless prompt some comments, our focus being on points of general interest in a cross-linguistic perspective rather than on languagespecific details concerning individual words. The basic question is why there is such variation in the use of loan translations across languages, as reflected in Table 6 . In this connection, we should not lose sight of the fact that loan translation is not the only device available to languages for creating indigenous alternatives to direct loans. 
The top language as regards loan translation, far ahead of the others, is Icelandic, featuring no less than 15 loan translations out of 25 possible ones. In a way, this may be considered an expected outcome in view of the fact that Icelandic ended up second from the bottom as regards direct loans (see Table 4). In all likelihood, it might be argued, the outstanding Icelandic result for loan translation is only a natural consequence of the successful purist language policy, commented on earlier (Section 3.2), long adhered to by the Icelanders. However, while clearly valid for Icelandic, such a conclusion would run the risk of positing a more or less automatic, inverse relation between direct loans and loan translations in our material and in languages in general. The case of Finnish shows why such a presupposition is problematic.

With regard to direct loans, Finnish occupies the bottom position by a large margin, with only six direct loans (as opposed to ten for Icelandic; see Table 4). If the Icelandic 'logic' - i.e. few direct loans = many loan translations - had been generally applicable, Finnish should, a fortiori, have exhibited an even larger number of loan translations than Icelandic. This is not the case, however. Instead, according to Table 6, Finnish (together with Romanian and Spanish) displays only two loan translations. What this means is simply that Finnish, along with many other languages at various genetic and typological distances from English, has opted for other equivalent expressions than what may, technically, be termed loan translations, according to $D E A$, to express the meanings of the corresponding English football terms (see Hakala 2007:143ff.). For some reason, the direct translation strategy inherent in loan translation has been avoided.

A comparison with Norwegian is also instructive, strengthening the impression that there does not appear to be a predictable inverse relation between the number of direct loans and the number of loan translations in a language - at least not when it comes to football vocabulary. Norwegian finds itself at the very top as far as direct loans are concerned (23 occurrences; see Table 4) but is by no means at the very bottom when it comes to loan translations (six occurrences); see Omdal (2007). A similar story applies to German: a fairly large number of direct loans (16 occurrences; see Table 4) and the same number of loan translations as Norwegian.

At the bottom of the table we find Croatian, Greek, Polish and Albanian, languages with just a single realization of loan translation, or none at all. These languages, then, can also be cited as evidence that loan translation does not appear to be a favoured strategy with all languages as far as native alternatives to direct loans are concerned. For example, Albanian shows twelve direct loans (see Table 4) but no loan translation. Obviously, Albanian must have filled the remaining 13 'conceptual gaps' (out of the 25 English football terms) with indigenous alternatives of other types, not classified as loan translations in DEA.

The question remains why some languages seem to be more favourably disposed towards loan translation than others, which apparently prefer other alternatives to direct football loans. However, this issue, of great interest in itself, is beyond the 
scope of the present study, even though various sociolinguistic factors, especially those relating to national attitudes and language-planning policies with regard to borrowing, are obviously relevant, as exemplified by Icelandic; for some discussion, see Bergh \& Ohlander 2012b:294ff. (see also Section 3.2). Further, some of the purely linguistic factors mentioned earlier - genetic and/or typological relatedness, ease of compounding, translatability, etc. - should be worth exploring. For now, however, we simply note that three Germanic languages (Icelandic, German and Norwegian) show the greatest propensity of the 16 languages to use loan translations.

Still, even with the limitations of the present study, the proportion between loan translations and direct loans in our material is clearly of interest. Allowing for the methodological problems noted, loan translation does not, generally speaking, seem to be the favourite way of all - or even most - languages to 'replace' direct loans. This point will be further elaborated as we move on to consider the main findings in Sections 3 and 4 in a combined perspective, where the relationship between direct loans and loan translations in our material will be further pursued.

\section{A COMBINED PERSPECTIVE: LOAN TRANSLATIONS IN RELATION TO DIRECT LOANS}

In simplified terms, roughly corresponding to most classifications of borrowing strategies, the decision-making process implicit in importing new and necessary concepts from one language to another in a specific domain, such as football, can be schematically outlined as follows:

(i) Use of direct loans or indigenous material?

(ii) If indigenous material: loan translations (including semantic borrowing) or other native-language creations (i.e. not involving direct translation, such as neologisms and paraphrases)?

Both direct loans and loan translations exhibit a clearly recognizable relation - formal and/or semantic - between the source (exporting) language (English, in our case) and the target (importing) language.

In the previous sections, the relationship between direct loans and loan translations has frequently been commented on, while different types of indigenous creations relating to the 25 football English football terms investigated have been mentioned only in passing, where relevant to basic issues concerning the power of balance between direct borrowing and loan translation in the 16 languages investigated.

The time has now come to consider these two borrowing strategies from a combined, unified perspective, where the frequency numbers for these two types of borrowing, accounted for in Sections 3 and 4, are treated together. This will 
provide a fuller picture of the relationship between loan translations and direct loans in the football domain, clarifying what the different patterns of borrowing add up to, for individual words as well as for individual languages, especially their overall proneness to accept English loans in one form or another. Again, it should be borne in mind that there is no mutually exclusive relationship between direct loans and loan translations: the same English word may turn up as both a direct loan and a loan translation in the same language, according to $D E A$; further, there are other types of indigenous alternatives to direct borrowing than loan translation, i.e. more independent creations bearing no obvious or direct relation to the English term.

In Table 7, the combined results are given for the 'direct loanability' and 'loan translatability' of each of the 25 football words included in the study. It is ordered according to decreasing total ('collapsed') frequency of direct loans and loan translations, thus accounting for the relative propensity of each of the English words to be borrowed by the 16 languages. The first column presents the English words investigated across the target languages. The second column gives the number of languages in which the relevant English word has been adopted as a direct loan (first figure), followed by the number of languages where it has been converted into a loan translation (second figure), in turn followed by the total number of loans, i.e. direct loans and loan translations combined (third figure). For instance, the English word kick-off turns up as a direct loan in six languages and as a loan translation in two, adding up to a total of eight loan occurrences in the languages investigated (not necessarily, however, in eight different languages).

\begin{tabular}{llll}
\hline & $\begin{array}{l}\text { Number of languages: } \\
\text { direct loans and loan } \\
\text { English words }\end{array}$ & English words & $\begin{array}{l}\text { Number of languages: } \\
\text { tirect loans and loan } \\
\text { translations }\end{array}$ \\
\hline corner & $14+11=25$ & forward & $9+3=12$ \\
football & $12+9=21$ & hands & $7+5=12$ \\
offside & $15+3=18$ & shoot & $9+2=11$ \\
penalty & $12+6=18$ & kick-off & $6+2=8$ \\
back & $12+5=17$ & keeper & $5+2=7$ \\
team & $16+1=17$ & cross & $4+1=5$ \\
hat-trick & $14+2=16$ & supporter & $4+0=4$ \\
hooligan & $15+1=16$ & sweeper & $2+2=4$ \\
dribble & $14+1=15$ & tackle & $4+0=4$ \\
goal & $14+1=15$ & score & $3+0=3$ \\
derby & $14+0=14$ & draw & $2+0=2$ \\
match & $14+0=14$ & head & $1+1=2$ \\
coach & $12+0=12$ & & \\
\hline
\end{tabular}

Table 7. Direct loans and loan translations combined in the 16 languages. 
Naturally, the combined numbers for the two types of loan tend to reflect the general frequency patterns presented in Tables 3 and 5 above. This applies in particular to the distribution of direct loans, which, as noted earlier, accounts for about 80 per cent of the data (see Section 4.1). Thus, the top group identified in Table 3 stays more or less intact, although the words corner and football have now made it to the top due to their relatively frequent occurrence as loan translations (11 and 9 instances, respectively). Similarly, with virtually no loan translations to boost their overall rank, apart from the odd cases of sweeper and head, the bottom group consists of the same six words as before, the only difference being that most of the verbs, i.e. tackle, score and head (draw is here classified only as a noun; see Section 2), have now struck the bottom of the table.

Further, given the combined numbers presented in Table 7, it is of interest to note that six of them actually exceed the total number of languages (16) included in the study. In addition to corner and football (recorded as loans 25 and 21 times, respectively), this applies to offside and penalty (18 instances) as well as back and team (17 instances). This illustrates the circumstance that a particular English football word can be represented as both a direct loan and a loan translation in one and the same language, although not necessarily with the same frequency of occurrence, and often with a difference in style, range, usage, etc. (see Section 4.1). Besides the cases mentioned earlier, a good example is to be found in Icelandic, where English back is realized as a direct loan (bakk) as well as a loan translation (bakvörður) (see Jansson 2013), or the word penalty in Dutch, rendered in parallel manner both as a direct loan (penalty) and as a loan translation (strafschop). By the same token, in Finnish, despite its generally restrictive approach to foreign loans (see Hakala 2007), the word football has been taken over both as a (modified, 'clipped') direct loan (futis) and as a loan translation (jalkapallo). As indicated by these examples, such dual usage is clearly not restricted to languages that readily accept loans from English, but may also occur in languages showing the opposite tendency.

The analysis of the combined data may be completed by considering the overall disposition of individual languages to accept English words from the football domain, as direct loans and/or loan translations. Table 8 below provides the relevant numbers. It displays great variation among the 16 languages as regards their overall inclination to accept English loans. At the same time, the combined perspective of the two types of borrowing yields a rather neat picture of the languages studied. At the top of the table, we now find the full quartet of Germanic languages, with Norwegian in front position with no fewer than 29 instances, followed by Icelandic (25), Dutch (23) and German (22). It can further be noted that the prominence of Norwegian and Icelandic is due to reverse tendencies, or preferences, commented on earlier: while Norwegian owes its position mainly to its striking number of direct loans, Icelandic stands out by virtue of its uniquely large number of loan translations, the odd man 
out in comparison with all the other languages, a reflection of its traditionally adverse attitude to direct loans (see Sections 3.2 and 4.1).

\begin{tabular}{llll}
\hline Languages & $\begin{array}{l}\text { Number of direct loans } \\
\text { and loan translations }\end{array}$ & Languages & $\begin{array}{l}\text { Number of direct loans } \\
\text { and loan translations }\end{array}$ \\
\hline Norwegian & $23+6=29$ & Romanian & $16+2=18$ \\
Icelandic & $10+15=25$ & Croatian & $16+1=17$ \\
Dutch & $20+3=23$ & French & $14+3=17$ \\
German & $16+6=22$ & Russian & $14+3=17$ \\
Bulgarian & $13+5=18$ & Spanish & $15+2=17$ \\
Greek & $17+1=18$ & Polish & $14+1=15$ \\
Hungarian & $15+3=18$ & Albanian & $12+0=12$ \\
Italian & $15+3=18$ & Finnish & $6+2=8$ \\
\hline
\end{tabular}

Table 8. Propensity of the 16 languages to use direct loans and loan translations.

The middle part of Table 8 - admittedly, with somewhat blurred contours is dominated by Romance and Slavic languages, with loans in the range of 15-18 instances. Finally, Albanian and Finnish are firmly established at the bottom of the table, with 12 and 8 instances, respectively. In this connection, it is interesting to note the clear difference between Finnish and Hungarian (18 instances), the two non-Indo-European, genetically related (Uralic) languages among those studied, providing further supporting evidence that genetic or typological distance is not in itself sufficient to explain differences in loanword frequency between different languages.

Summing up, a combined perspective of direct loans and loan translations confirms the impression that the 16 languages studied diverge considerably in their overall approach to foreign loans in the football domain. The most distinctive aspect of the combined numbers is the clear predominance of the Germanic languages in general, and - in particular - the advance of Icelandic to runner-up position, brought about by its outstanding number of loan translations. Comparatively speaking, it is also noteworthy that the languages in this group distinguish themselves by allowing, on average, more than twice as many loans as the languages in the bottom group. As suggested earlier, it may reasonably be assumed that a combination of purely linguistic factors and sociolinguistic ones, relating to attitudinal differences and language planning efforts over time, underlies the differences observed - even though the field seems to be marked by a great deal of unpredictability.

\section{GENERAL DISCUSSION}

Overall, the most striking outcome of our study concerns the proportion between direct loans and loan translations in the material investigated. In comparison with 
direct loans, loan translations of the 25 football terms turned out to be much less frequent, only 20 per cent of the combined total of direct loans and loan translations. At first glance, this may well be regarded as somewhat unexpected as it would seem to imply that direct borrowing makes up the most common means for European languages to accommodate English football vocabulary, relegating loan translation to a minority position. However, as emphasized in Section 4.1, this is an unwarranted conclusion, a partial consequence of the circumstance that the selection of the 25 words was based on the words included in DEA, and thus - due to its stated principles for inclusion - biased in favour of direct loans at the expense of loan translations. In this sense, then, our material can lay no claim to being a representative sample of football terms in general; the material is skewed towards direct football loans.

For example, as noted earlier, common football terms like free kick, (goal)post and pitch do not qualify for inclusion in DEA, and thus not in our material, since according to $D E A$ - they do not occur as direct loans in any of the 16 languages. Had they, and similar football words, been included, the proportion of loan translations in relation to direct loans would have looked different. In other words, a more 'neutral', random selection of football terms beyond those found in DEA would probably have yielded a different result, where it may be assumed that direct loans would hardly outnumber indigenous expressions such as loan translations. Such an approach, however, would have made a systematic comparison of the 16 languages and the 25 words much more cumbersome; the strength of $D E A$ is that it provides a unified and convenient source of detailed, specialist information about English loans in a large representative sample of European languages.

However, despite the methodological issues just mentioned, the material studied suggests that, in the 16 languages investigated, loan translation does not, overall, seem to be the chief way to create native alternatives to direct loans, with the notable exception of Icelandic (see Table 6). Why this is so is not clear, even though there may be linguistic factors at work - formal/structural (including phonological) as well as semantic - promoting or counteracting the kind of direct translation that typically underlies loan translation. Genetic and/or typological distance may also be relevant here, although only to a limited extent, as we have seen earlier on; see e.g. the differences between Norwegian and Icelandic. Obviously, this is a field in need of further exploration.

Generally speaking, the result of our study indicates a conspicuous lack of homogeneity with regard to borrowing, regardless of whether the starting point is provided by the 25 English football words or by the 16 European languages. There are striking differences between individual words concerning their proneness to be taken over as direct loans in the languages investigated (compare e.g. team and head, hooligan and sweeper, penalty and draw; see Table 3), or conversion into loan translations (compare corner and tackle, football and derby, penalty and score; see Table 5). Likewise, there are drastic differences between languages when 
it comes to direct borrowing (compare e.g. Norwegian, Dutch and Greek versus Albanian, Icelandic and Finnish; see Table 4) or to loan translation (compare e.g. Icelandic, German and Norwegian versus Greek, Polish and Albanian; see Table 6). Again, it is instructive to note the divergence between Norwegian and Icelandic, two closely related Nordic languages, or between Finnish and Hungarian, the two Uralic languages in the $D E A$ material.

The outcome of the study thus shows that there is a great deal of variation both between the individual words and between the languages studied. Overall, combining direct loans and loan translations (Section 5), the Germanic languages stand out, forming the top group with regard to English influence in their football lexis (see Table 8). Other languages exhibit a more marginal proportion of direct or indirect English influence. With regard to direct loans, however, a slightly different picture presents itself. The language at the very top of the league table for direct loans is Norwegian (Table 4), whereas two other North European languages, Icelandic and Finnish, occupy the two lowermost positions. On the other hand, Icelandic fights back when it comes to loan translations, finding itself, by an impressive margin, in topmost position - in many ways, an expected outcome in view of Icelanders' traditional policy of avoiding direct loans in favour of indigenous equivalents such as loan translations (see e.g. Óladottir 2009:131f.).

However, the DEA material investigated here hardly invites any far-reaching conclusions as to WHY the results look the way they do. To be sure, Icelandic may be regarded as exceptional in this respect, there being an unusually straightforward causal relation between an official language-planning policy and the findings in the present study. In most other cases, the circumstances relevant to the interplay between individual English football words and individual languages are simply too numerous, complex and random for predicting what the result of such cross-linguistic encounters will be in individual cases. In this connection, attitudinal and other changes over time in specific language communities may also be mentioned, being largely unpredictable (see below). Consequently, it is virtually impossible to tell, for a certain language at a certain time, whether a specific word is likely to be adopted as a direct loan or converted into an indigenous equivalent expression (barring Icelandic and, possibly, a few other languages). This means that what we are usually left with is explanation after rather than before the event.

Even so, certain tendencies can be discerned from the multi-tier perspective words versus languages, direct loans versus loan translations - used in our investigation. Since the combined effect of direct loans and loan translations in relation to the languages studied has already been treated (Section 5), with four Germanic languages at the top, the following comments will briefly consider some of the factors that may be relevant to the data accounted for (see also Bergh \& Ohlander 2012b).

As regards the 25 English football words and their adoption as direct loans in the 16 European languages, it seems reasonable to assume that certain purely 
linguistic factors have played a role, although not the same role in the individual borrowing languages. A word may be more or less readily adopted as a direct loan in different languages, requiring greater or smaller adjustments, or adaptations, in relation to phonological/orthographic and morphological properties of the borrowing language (see e.g. Sandøy \& Östman 2004). It could be hypothesized that phonological and/or morphological factors, i.e. relative degree of similarity between English and the borrowing language, may facilitate the process of transition and subsequent assimilation in the borrowing language. This, it may be argued, should apply especially to pronunciation and inflection, at least to begin with, as a contributory circumstance. Possibly, it is no coincidence that a phonologically simple, monosyllabic word like team, whose pronunciation (as opposed to spelling) should hardly be a problem to speakers of other languages, turns up in the number one position among the 25 English words investigated, being a direct loan in all the 16 languages. Another frequent, phonologically simple direct loan in the 16 languages is the noun back, occurring in 12 languages (see Table 3); a further example is goal, where the English diphthong is usually rendered as a simple vowel, e.g. in Spanish.

The assumed importance of the relative degree of closeness or similarity - genetic and/or typological - between English and the borrowing languages might draw some further support from the fact that two Germanic languages (Norwegian and Dutch) are in the lead for direct loans (see Table 4), as well as from the rock-bottom position of Finnish. On the other hand, as already pointed out, the case of Icelandic speaks against any strong causal relation as far as structural linguistic similarity is concerned; obviously, linguistic similarity of the kind discussed here may be overruled by other factors. In fact, closer inspection of the relevant data suggests that formal similarity appears to play a subordinate role in direct borrowing, as also evidenced by the fact that English football terms like offside and dribble - whose phonological makeup is considerably more complex than that of e.g. team and back - are widespread as direct loans among languages, regardless of their degree of similarity to English (see Table 3).

For words like offside and dribble, semantic complexity, or specificity, appears to hold more promise than structural similarity in the quest for explanations as to why some words are more prone to direct borrowing than others. It is closely related to the notion of translatability, i.e. the relative ease with which a term can be translated into another language without losing the special meaning associated with it. As noted earlier, the word offside is notoriously difficult to define succinctly - and thus to translate. This also applies, although to a lesser degree, to dribble as well as many other English football words. It is thus no wonder that these two words turn up as direct loans in nearly all the 16 languages. The semantic complexity or specificity of these words is a reminder that football language is indeed a special language despite its widespread familiarity. 
However, apart from purely linguistic factors, of a formal/structural and semantic nature, there are other circumstances, of a socio-cultural kind, affecting the propensity of individual languages to adopt direct loans and thus, indirectly, the number of loan translations in our material. As already suggested, it appears that cultural and sociolinguistic factors like current attitudes and stated policy in relation to foreign languages or a specific foreign language, English in our case - have exerted far greater influence than purely linguistic ones. Again, this is particularly well illustrated by the striking contrast between Icelandic and Norwegian, two closely related North Germanic languages, with Norwegian at the top of the direct-loan table and Icelandic at the top, in even more splendid isolation, with regard to loan translations (see Tables 4 and 6).

Thus, different policies and attitudes towards language planning and maintenance, especially concerning direct loans (see e.g. Görlach 2002, Sandøy $\&$ Östman 2004), clearly affect the number of direct loans and loan translations in different languages, at different times; even neighbouring countries may differ widely. A direct loan may have entered a language during a period of relative tolerance towards direct loans, later to be supplanted by purist attitudes manifested in a policy of resistance to direct loans, in turn promoting the introduction and use of indigenous terms - or the other way around; compare German offside and abseits, Team and Mannschaft (Busse \& Görlach 2002:16). The 20th century saw many changes, not always along predictable lines, in the response of different languages to English football terms; consistency and linearity in the history of individual languages with regard to borrowing should not be expected.

Moreover, beyond collective attitudes and policies, there seems to be a considerable element of personal influence at work as regards the use of English direct loans or native equivalents in the football domain. At a time when English is the world's primary lingua franca - not least among players in international teams (see Ringbom 2012) - influential commentators and 'pundits' in different media play a significant role introducing new concepts and terms (e.g. of a technical or tactical nature), as well as new, more trendy terms for old phenomena, setting the pattern for new football usage in the form of direct loans or loan translations. This means that football language, like general language, is subject to a considerable degree of trendiness, where prestigious media personalities, as well as influential coaches and managers, play a key role in shaping it.

Not infrequently, this may lead to new direct loans being used alongside wellworn native-language expressions. In Swedish, for example, the word straffområde (a well-established loan translation of penalty area) has recently found itself in competition with the synonymous English direct loan box (short for penalty box). Similarly, though resulting in loan translations instead, it is now common for Swedish TV commentators to use expressions like sittande (mittfältare), i.e. sitting (midfielder), alongside of the (roughly synonymous) old term defensiv (mittfältare), i.e. defensive (midfielder); another recent loan-translation example originating from 
TV commentators is the novel football use of the Swedish phrasal verb sätta upp, modelled on English set up in the specific footballing sense of (roughly) 'to pass the ball to a player in a position to score', competing with the already existing, synonymous Swedish expression spela fram. ${ }^{16}$ These examples all show the largely unpredictable, idiosyncratic influence of football commentators in the media, resulting in new direct loans or loan translations. More generally, they may be seen as present-day instances of ongoing change in a specific field of Swedish vocabulary, but with a bearing on vocabulary change at large, in other languages as well, especially with regard to the impact of today's media. In this connection the role of the ubiquitous Internet and social media should not be ignored, helping to speed up the public breakthrough and spread of new words, in the football domain and elsewhere.

\section{CONCLUDING REMARKS}

As opposed to Bergh \& Ohlander (2012b), where direct football loanwords in European languages were our primary concern, the main focus of the present study has been on loan translations in a wide sense. At the same time, a full picture of the borrowing patterns and processes involved in football vocabulary, concerning both the original 25 English words and the 16 European languages studied, presupposes a kind of split vision, a dual perspective where both types of borrowing are related to each other. Such a perspective, comparative in nature, has been present in the preceding sections.

What, then, can be concluded as to why the results of the present study look the way they do, especially the clear cross-linguistic preponderance of direct loans in comparison with loan translations? To be sure, part of the explanation derives from certain methodological problems and limitations inherent in the material investigated: the direct-loan bias in $D E A$, its implementation of the notion of 'loan translation', etc. Apart from that, the overall picture, i.e. the distribution of direct loans versus loan translations for the words and the languages investigated, can be at least partially and tentatively accounted for in terms of linguistic notions like semantic complexity or specificity, where translatability is key. Formal/structural factors, including phonological ones, may also have some relevance in a crosslinguistic loanword perspective, such as that adopted here. By contrast, relative distance, genetic or typological, seems to be of minor importance in the material studied. On the whole, purely linguistic circumstances seem clearly less significant in accounting for the borrowing patterns found in the different languages than those related to sociolinguistically potent variables, such as attitudes and language-planning policies in different language communities, as well as changes over time in the same language community. 
The main impression, however, is one of heterogeneity and unpredictability: there are striking differences between the 25 words studied as well as between the 16 languages investigated with respect to direct loans and loan translations. In view of the corresponding heterogeneity - linguistically, socio-culturally and historically - of Europe in the 20th century, when football and English football language conquered the world, such a result is hardly surprising.

To get a more complete view of the processes underlying the outcome of the present study, there is clearly need for further research, on a broad methodological canvas, into the complex interplay of factors that have affected European and other language communities in the past hundred years or so, causing them to react in different ways to the flood of football English to which they have been exposed. This would not only increase our understanding of the global spread of football vocabulary in the past. It could also, as the game and its language move on, provide a sense of direction about the future of direct loans and loan translations in the world's most widespread special language.

\section{ACKNOWLEDGEMENTS}

We would like to express our gratitude to our three anonymous $N J L$ referees for their close and perceptive reading of the text and, in particular, for their constructive criticism and valuable suggestions.

\section{NOTES}

1. Compare also more colloquial terms such as footballspeak and football talk (Seddon 2004) or the slightly derogatory footballese, often referring to the overuse of clichés by football pundits (see Hilton 2007).

2. For some discussion of the relations between football language, sports language and general language, see Bergh \& Ohlander (2012a:15).

3. For discussion of some specific syntactic features of English and Swedish football verbs, see Bergh \& Ohlander (2016).

4. As will be discussed later (Section 4.1), the term 'loan translation' will here be used in a wide sense, also including instances of what are often referred to as 'semantic loans', e.g. Swedish hörna, a direct translation of English corner.

5. Kristiansen \& Sandøy (2010) provides an introduction to a special issue (in English) of the International Journal of the Sociology of Language, Issue 204 (July 2010), accounting for the design and the main results of the MIN project.

6. By contrast, draw is classified only as a noun in $D E A$, i.e. not as a verb.

7. See Görlach (2002:8), where it is noted that 'the number of verbs borrowed straight from English is comparatively small in all European languages'; see also Haugen (1950:224).

8. Incidentally, ball games ('boldspil') make up one of the thematic domains studied from the perspective of Nordic-language borrowing and accounted for in Kvaran (2007c:172f.); in 
this group of words are to be found, among others, three of the football words investigated in the present context: corner, offside and team.

9. In particular, with regard to the relationship between direct loans and loan translations, it should be noted that some words, in some language(s), may have started out as direct loans, later to be replaced by - or coexist with - corresponding loan translations, e.g. Team versus Mannschaft in German. Also, to be regarded as a direct football loan, a word must have an identifiable footballing meaning in the relevant language, according to $D E A$; for example, the words coach and derby may refer to football, as well as to other domains.

10. Consider $O D E$ : 'take (the ball) forward past opponents with slight touches of the feet' (dribble); '(of a player) . . occupying a position on the field where playing the ball $\ldots$ is not allowed, generally through being between the ball and the opponent's goal' (offside). Neither definition can be regarded as completely adequate.

11. For example, as regards German, Busse \& Görlach (2002:16) note that a campaign was launched in the early 20th century against the 'excessive use of Anglicisms', proposing German equivalents, football being one of the targeted domains. In this context, they note that '[i]t is interesting to find that in football almost all the proposed translations are still in use ... but that the Anglicisms under attack largely survive (at least as alternatives) in Austria and Switzerland'.

12. Consider, for instance, the following example, from Graedler \& Johansson (1997:105), of the Norwegian predilection for English direct loans: Nok en gang [scoring] på en vakker heading etter corner 'Once more scoring from a beautiful header after a corner'.

13. Cf. e.g. the Swedish Språklag [Language Act] of 2009 (SFS 2009:600). For other examples, see Görlach (2002). For discussion of some practical and theoretical aspects of language planning, see Haugen (1983); for an international survey of language-planning issues and progress in the 20th century, see Cobarrubias \& Fishman (1983).

14. Consider DEA (corner): 'The compound corner-kick was also widespread in the early twentieth century'. Incidentally, corner-kick rendered as Norwegian hjørnespark may be seen as a classic example of loan translation, involving a compound noun in both languages, whereas (to some scholars) the simple word corner rendered as Norwegian hjørne would be a clear example of semantic borrowing. This also shows, as argued earlier, the irrelevance, in the present context, of making a strict distinction between these two types of borrowing, as opposed to direct loans.

15. For example, German abseits is certainly a transparent loan translation from a morphological point of view; semantically, however, it is hardly more transparent than offside (see Section 3.1).

16. Interestingly, this sense of English set up is not accounted for in the $O E D$.

\section{REFERENCES}

Baker, Mona (ed.). 1998. Routledge Encyclopedia of Translation Studies. London: Routledge. Battarbee, Keith. 2002. Finnish. In Görlach (ed.), 261-276.

Bergh, Gunnar \& Sölve Ohlander. 2012a. Free kicks, dribblers and WAGs: Exploring the language of 'the people's game'. Moderna Språk 106, 11-46.

Bergh, Gunnar \& Sölve Ohlander. 2012b. English direct loans in European football lexis. In

Cristiano Furiassi, Virginia Pulcini \& Félix Rodríguez González (eds.), The Anglicization of European Lexis, 281-304. Amsterdam \& Philadelphia, PA: John Benjamins. 
Bergh, Gunnar \& Sölve Ohlander. 2014. Unlucky Rooney hits bar in Newcastle. Om falsk fotbollsvänskap mellan engelskan och svenskan [Unlucky Rooney hits bar in Newcastle: On false football friendship between English and Swedish]. In Karin Helgesson, Hans Landqvist, Benjamin Lyngfelt, Jenny Nilsson \& Catrin Norrby (eds.), Fint språk/Good language. Festskrift till Lars-Gunnar Andersson (Meierbergs arkiv för svensk ordforskning 41), 21-34. Göteborg: Göteborgs universitet.

Bergh, Gunnar \& Sölve Ohlander. 2016. Iniesta passed and Messi finished clinically: Football verbs and transitivity. Nordic Journal of English Studies 15(2), 19-38.

Berteloot, Amand \& Nicoline van der Sijs. 2002. Dutch. In Görlach (ed.), 37-56.

Busse, Ulrich \& Manfred Görlach. 2002. German. In Görlach (ed.), 13-36.

Cobarrubias, Juan \& Joshua Fishman (eds.). 1983. Progress in Language Planning: International Perspectives. Berlin: De Gruyter Mouton.

Crystal, David. 2003. English as a Global Language. Cambridge: Cambridge University Press.

Crystal, David. 2010. The Cambridge Encyclopedia of Language, 3rd. edn. Cambridge: Cambridge University Press.

$D E A=$ Görlach 2001.

Edlund, Lars-Erik \& Birgitta Hene. 1992. Lånord i svenskan [Loanwords in Swedish]. Höganäs: Wiken.

Giulianotti, R. 1999. Football: A Sociology of the Global Game. Cambridge: Polity Press. Goldblatt, David. 2007. The Ball is Round: A Global History of Football. London: Penguin. González, Félix Rodríguez. 2002. Spanish. In Görlach (ed.), 128-150.

Görlach, Manfred (ed.). 2001. A Dictionary of European Anglicisms. Oxford: Oxford University Press.

Görlach, Manfred (ed.). 2002. English in Europe. Oxford: Oxford University Press.

Graedler, Anne-Line. 2002. Norwegian. In Görlach (ed.), 57-81.

Graedler, Anne-Line \& Stig Johansson. 1997. Anglisismeordboka [The Anglicism dictionary]. Oslo: Universitetsforlaget.

Hakala, Hanna. 2007. Ersättningsord i finskan [Adaptation of foreign words in Finnish]. In Kvaran (ed.), 135-168.

Haugen, Einar. 1950. The analysis of linguistic borrowing. Language 26, 210-231.

Haugen, Einar. 1983. The implementation of corpus planning: Theory and practice. In Cobarrubias \& Fishman (eds.), 269-290.

Hiidenmaa, Pirjo \& Pirrko Nuolijärvi. 2004. Normering av främmande ord i finskan [Standardization of foreign words in Finnish]. In Sandøy \& Östman (eds.), 253-274.

Hilton, Dominic. 2007. How to speak footballese. The Lizard. Available at http://www.lizardmagazine.com/hiltonfootballese.html (accessed 25 March 2011).

Jansson, Håkan. 2013. Bakk or bakvörður - on loans and induced linguistic innovations in Icelandic football lexis. In Gunnar Bergh, Rhonwen Bowen \& Mats Mobärg (eds.), Language, Football and All That Jazz: A Festschrift for Sölve Ohlander (Gothenburg Studies in English 100), 157-168. Gothenburg: University of Gothenburg.

Jansson, Håkan. 2015. Purism på glid. Studier i nutida isländskt ordbruk [Purism on the slide? Studies in present-day Icelandic word usage] (Göteborgsstudier i nordisk språkvetenskap 24). Göteborg: Göteborgs universitet.

Kristiansen, Tore \& Helge Sandøy. 2010. Introduction. The linguistic consequences of globalization: The Nordic laboratory. International Journal of the Sociology of Language 2010(204), 1-7. 
Kristiansen, Tore \& Lars S. Vikør (eds.). 2006. Nordiske språkhaldningar. Ei meiningsmåling [Nordic language attitudes: A measurement of opinions] (Moderne importord i språka i Norden IV). Oslo: Novus forlag.

Kvaran, Guðrún (ed.). 2007a. Udelandske eller hjemlige ord? En undersøgelse af sprogene $i$ Norden [Foreign or domestic words? An investigation of the languages in the Nordic countries] (Moderne importord i språka i Norden VI). Oslo: Novus forlag.

Kvaran, Guðrún. 2007b. Importord og aflösningsord i islandsk [Import words and replacement words in Icelandic]. In Kvaran (ed.), 19-48.

Kvaran, Guðrún. 2007c. Brug af afløsningsord i de nordiske sprog. Sammenligning og konklusioner [The use of replacement words in the Nordic languages: Summary and conclusions]. In Kvaran (ed.), 169-187.

Kvaran, Guðrún \& Ásta Svavarsdóttir. 2002. In Görlach (ed.), 82-107.

Ljung, Magnus. 1988. Skinheads, hackers och lama ankor. Engelskan i 80-talets svenska [Skinheads, hackers and lame ducks: English in the Swedish of the 1980s]. Stockholm: Trevi.

$O D E=$ Oxford Dictionary of English. 2010. Oxford: Oxford University Press.

$O E D=$ Oxford English Dictionary Online. 2010. Available at http://www.oed.com (accessed 2 June 2014).

Óladóttir, Hanna. 2009. Shake, sjeik eller mjólkurhristingur? Islandske holdninger til engelsk språkpåvirkning [Shake, sjeik or mjólkurhristingur? Icelandic attitudes towards the influence of English] (Moderne importord i språka i Norden XI). Oslo: Novus forlag.

Omdal, Helge. 2007. Både e-mail og e-post? Om avløyserord i norsk [Both e-mail and e-post? On replacement words in Norwegian]. In Kvaran (ed.), 49-75.

Pulcini, Virginia. 2002. Italian. In Görlach (ed.), 151-167.

Ringbom, Håkan. 2012. Multilingualism in a football team: The case of IFK Mariehamn. In Danuta Gabrys-Barker (ed.), Cross-linguistic Influences in Multilingual Language Acquisition, 185-197. Berlin: Springer.

Sager, Juan, David Dungworth \& Peter McDonald. 1980. English Special Languages.

Wiesbaden: Oscar Brandstetter.

Sandøy, Helge \& Jan-Ola Östman (eds.). 2004. 'Det främmande' i nordisk språkpolitik. Om normering av utländska ord ['The foreign' in Nordic language policies: On national norms concerning foreign words] (Moderne importord i språka i Norden II). Oslo: Novus.

Schütte, Dagmar. 1996. Das schöne Fremde. Anglo-amerikanische Einflüsse auf die Sprache der deutschen Zeitschriftenwerbung. Opladen: Westdeutscher Verlag.

Seddon, Peter. 2004. Football Talk. London: Robson Books.

SFS 2009:600 = Svensk författningssamling 2009: 600, Språklag. [Language Act]

Stålhammar, Mall. 2010. Engelskan i svenskan [English in Swedish]. Stockholm: Norstedts. 